\title{
Induced Innovation with Endogenous Growth in Agriculture: A Case of Japanese Rice Production
}

\author{
Shunji Oniki*
}

\begin{abstract}
An endogenous growth mechanism of productivity is incorporated into a neoclassical induced innovation model. The time-series-based econometric analysis on Japanese rice production provides evidence supporting the technological change process of learningby-doing and technological spillover. The learning-by-doing effect is confirmed by cointegration between the capital and the total factor productivity (TFP), and the technological spillover effect is confirmed by the Granger-causality tests for the TFP of largescale producers and that of small-scale producers. The cointegrating relationship between capital and labor series shows the presence of a long-run growth path in production. The error correction model of the production function illustrates the endogenous technological change process. Presence of the externality in innovation implies that a capitalintensive technology is likely to be created. Improvement in product quality is indirectly induced by diminishing returns to capital and it also has a spillover effect, so that it may also be regarded, in a broad sense, as a part of the endogenous innovation effect.
\end{abstract}

Key words: technological change, endogenous growth, time-series analysis.

\section{Introduction}

Technological changes are often expressed by an exogenous time trend in econometric models for agricultural production. Although the deterministic trend process may sometimes provide well-behaved approximation of technological progress, it involves little economic reasoning. The induced innovation hypothesis presents a mechanism of endogenous technological change process in terms of factor substitution and has been tested on Japanese agriculture in a variety of econometrics studies, such as Kako [10], Kuroda [12], and Kawagoe et al. [11]. Even though the models

\footnotetext{
* National Research Institute of Agricultural Economics.

An earlier version of this paper was presented at the Japan Economic Association meeting, May13, 2000, Yokohama, Japan. The author particularly acknowledges comments and suggestions from Tetsushi Sonobe and anonymous referees of this Journal. Special thanks are also due to Tetsuro Yakushiji for providing a compiled data set and useful advice. The author is responsible for any remaining errors.
}

successfully illustrate endogenous technological changes in terms of factor substitution, the assumptions of exogeneity must be imposed in terms of technological progress, so that the technological progress is given in the models instead of being explained by economic factors.

Arrow [2] attempts to formulate an endogenous technological progress in a learning-bydoing model, and Sheshinski [22] extends this idea in a more formal representation. These models still have a problem that a grow th rate fall into zero in a long run. Using assumptions of instantaneous spillover and constant returns in a learning function, Romer [21] suggests the possibility of a long-run growth in the learning-by-doing framework. One distinct characteristic of the Arrow-Sheshinski-Romer model of learning-by-doing is its implication of a relationship between technological progress and capital investment. That is, learning and inventing associated with capital investment stimulate technological progress over the long run.

There are volumes of literature to prove that technological progress and the findings run 
against the argument that technological progress follows an exogenous trend. This study proposes to introduce the learning-bydoing growth mechanism into the induced innovation model. With regard to econometric analyses, methods of time-series analyses, such as cointegration analysis and a Grangercausality test, are applied to investigate the possibility of long-run growth and causal relationship suggested by the endogenous growth models. Empirical analyses are carried out for a case of Japanese rice production during the 1951-95 period. The implication of changes in product quality to the innovation is also explored in this paper.

\section{The Learning-By-Doing and Technological Spillover in Agriculture}

Neoclassical models of economic growth, such as the Solow-Swan model, assume exogeneity in technological progress. Although these models have an implication that long-run growth cannot be achieved without technological progress, they offer little explanation about the mechanism of technological progress. To analyze economic aspects of the growth, Arrow [2], Sheshinski [22], and Romer [21] develop learning-by-doing models, which postulate that a level of technical knowledge is approximated by an accumulated level of the capital and that the knowledge spills over an entire economy. Thus capital investment generates technological progress through the learning-by-doing and the spillover of the idea.

The main feature of the learning-by-doing model is that the overall stock of technological knowledge is raised by production practice itself. If a producer repeats the same practice in every period, few incentives to develop or adopt new technologies are created. The level of technical knowledge is enhanced as producers change their production process into a new form and make trials and errors to raise the productivity. Early learning-by-doing studies, such as Wright [25], consider learning through experience as a factor to raise the productivity of workers and use a cumulative output level as an index for a level of the experience. Arrow [2] proposes to use a cumulative level of capital for the knowledge index; thus the amount of capital investment in a period represents the index of technological improvement. Solow [24] points out that learning-by-doing means not merely an adjustment process through learning, but an invention and creation of alternative methods of production. Following Romer's [21] study, the endogenous growth theory has been further developed. The theory leads a different implication from the neoclassical growth theory. In the neoclassical model, a growth rate converges to zero if the economy is on a steadystate equilibrium, ${ }^{1)}$ but in an endogenous growth model it does not necessarily do so.

The possibility of long-run growth is examined by testing convergence in output per labor. Barro and Sala-i-Martin's [3] tests show evidence for the convergence. Yamaguchi and Chen [26] apply the convergence test developed by Barro and Sala-i-Martin for Japanese agriculture. Since few empirical studies in the past apply the endogenous growth theory for agricultural production, their study marks an epoch in agricultural growth analysis. However, it does not overcome a problem that the assumptions in a macroeconomic analysis are imposed on a microeconomic analysis of agricultural production. For instance, although it may be reasonable in macroeconomics to assume that the population of labor grows at a constant rate, it is usually assumed in a microeconomic problem that labor can be changed flexibly according to economic environment. Also, unlike macroeconomics, the steady-state condition in a microeconomic framework can hardly be presumed. Thus the Barro and Sala-i-Martin model cannot be applied directly to a microeconomic problem, such as agricultural production.

A few empirical studies on learning-bydoing in agricultural production have been conducted in the past. Most of the studies focus on learning effects in technological adoption at the village level (e.g., Foster and Rosenzweig [7], Cameron [4]). Although they show evidence of the learning at the farm lev. els, they do not explain how long-run growth is realized by it. To estimate the learning-bydoing effects, Luh and Stefanou [17] use a variable for a total amount of capital as a proxy for the knowledge level in an aggregate profit function model. Yet it is not preferable to include the capital variable in the model because of possible problems of simultaneous estimation and multicollinearity in the 
Induced Innovation with Endogenous Growth in Agriculture: A Case of Japanese Rice Production 17

estimation.

Turning now to the process of technological innovation in agriculture, an endogenous aspect of the innovation is also important for agricultural production. Although public research institutions are often responsible for technological innovation in agriculture, their research is carried out as being based on potential demand by the end users (i.e., farmers). If newly created technologies do not meet with their needs, they will not be applied to practice on farms. The innovation process involves interactions between the researchers and the users, rather than following a one-way supply from researchers to users (Rogers [20]). In other words, demand-driven or endogenous technological changes are as important as supply-driven technological changes (Pardey and Craig [19]). The demand aspect of innovations in public research has been widely recognized and tested empirically in literature on induced innovation (Ahmed and Ruttan [1]).

Furthermore, secondary innovation or development of a technology is as important as primary innovation or basic research carried out by a research institution. The secondary innovation is needed during a process of dissemination in the agricultural sector, since adoption of the technology is sensitive to local environment, such as climate, topography, and soil, as well as to socioeconomic situations. Since various decision-making processes are involved in dissemination, it is regarded as another development process of the technology. Thus the learning-by-doing process performed by farmers and extension workers is usually required in introducing new technology in the local environment. Once a new technology is established in an area, it becomes a nonexclusive good and information on it will then be available to neighboring areas. Thus technological spillover is a common practice in agriculture.

The key players for secondary innovations are often large farms, not small or marginal ones. Rogers [20] argues that innovative farmers tend to have less risk-averse preference, higher ability to use unfamiliar complex technologies, and better financial background. On this ground, this study assumes that those who practice technological innovations are relatively larger farms and that the new innovative ideas they create are transferred to other farms, most of which are small. In the next section, this innovation process is explained in a more formal representation.

\section{The Method}

Technological knowledge is assumed to be increased by capital investments, which lessens labor requirements, through the learning-bydoing process. The learning function is given by

$$
A_{i}(t)=\theta K_{i}(t)^{r}
$$

where $A_{i}(t)$ and $K(t)$ are respectively the level of technological knowledge and capital per labor for the producer $i$ at the time $t$, and $\theta$ and $\gamma$ are the parameters. Suppose that all producers have the same type of production process and the knowledge spills over to other producers free of charge; therefore the subscript $i$ may be omitted. Assuming constant returns to scale for the Cobb-Douglas production function, the isoquant curve is expressed by

$$
\ln l(t)=\ln \alpha-\eta \ln k(t)-\ln A(t)
$$

where $k(t)$ and $l(t)$ are the amount of capital and labor per unit of output at the time $t$. The long-run path is then given by

$$
\begin{aligned}
& \ln l(t)=\{\ln (\alpha / \theta)\} /(1-\gamma)-(\eta+\gamma) / \\
& \quad(1-\gamma) \ln k(t)
\end{aligned}
$$

When the variables are nonstationary, this model is valid only if they are cointegrated. In other words, if the variables are not cointegrated, no stable growth path exists.

The relationship of the variables may be expressed in the following error correction model:

$$
\begin{aligned}
\Delta \ln l(t)= & \eta \Delta \ln k(t)-\lambda[\ln l(t-1) \\
& -\ln \psi-\phi \ln k(t-1)]+\varepsilon(t)
\end{aligned}
$$

where $\ln \phi=\{\ln (\alpha / \theta)\} /(1-\gamma), \phi=-(\eta+\gamma) /$ $(1-\gamma)$. To incorporate effects of the exogenous technological changes, a time trend variable may be included in the equation:

$$
\begin{aligned}
& \Delta \ln l(t)=\eta \Delta \ln k(t)-\lambda[\ln l(t-1) \\
& \quad-\ln \psi-\phi \ln k(t-1)-\delta(t-1)]+\varepsilon(t)
\end{aligned}
$$

The equation 4 may be interpreted as a representation of the learning-by-doing process of technological change. The difference terms describe the short-run relationship, and the error correction term in parentheses represents the long-run path, which is uniquely identified only if the series are cointegrated. This model also illustrates that the variation in $\ln l$ is due to the variation in $\ln k$ in the production function plus the deviation of the production function from the long-run path. If the producer 
does not change the production process, the production function does not shift along the long-run path; in other words, technology does not progress.

Assume that the production process grows by the $p$-th order vector autoregressive (VAR) model:

$$
\begin{aligned}
& {\left[\begin{array}{l}
\ln k(t) \\
\ln l(t)
\end{array}\right]=\left[\begin{array}{c}
\delta_{k} \\
\delta_{l}
\end{array}\right]+\left[\begin{array}{c}
\beta_{k k}^{1} \beta_{k l}^{1} \\
\beta_{l k}^{1} \beta_{l l}^{1}
\end{array}\right]\left[\begin{array}{c}
\ln k(t-1) \\
\ln l(t-1)
\end{array}\right]+\cdots+} \\
& {\left[\begin{array}{c}
\beta_{k k}^{p} \beta_{k l}^{p} \\
\beta_{l k}^{p} \beta_{l l}^{p}
\end{array}\right]\left[\begin{array}{l}
\ln k(t-p) \\
\ln l(t-p)
\end{array}\right]+\left[\begin{array}{c}
\nu_{k}(t) \\
\nu_{l}(t)
\end{array}\right]}
\end{aligned}
$$

where $\nu_{k}$ and $\nu_{l}$ are the error terms. This model is used for examining Granger-causality between $\ln k$ and $\ln l$. If $\beta_{l k}$ is significantly different from zero, $\ln k$ will Granger-cause $\ln l$, and if $\beta_{k l}$ are significant, $\ln l$ will Granger-cause $\ln k$. If $\ln k$ and $\ln l$ follow $I(1)$ process and they are cointegrated, the Granger-causality is tested by the following error correction representation:

$$
\begin{aligned}
& {\left[\begin{array}{c}
\Delta \ln k(t) \\
\Delta \ln l(t)
\end{array}\right]=\left[\begin{array}{c}
\mu_{k} \\
\mu_{l}
\end{array}\right]+\left[\begin{array}{c}
\lambda_{k} E_{k}(t-1) \\
\lambda_{l} E_{l}(t-1)
\end{array}\right]+} \\
& {\left[\begin{array}{c}
\varphi_{k k}^{1} \varphi_{k l}^{1} \\
\varphi_{l k}^{1} \varphi_{l l}^{1}
\end{array}\right]\left[\begin{array}{l}
\Delta \ln k(t-1) \\
\Delta \ln l(t-1)
\end{array}\right]+\cdots+} \\
& {\left[\begin{array}{c}
\varphi_{k k}^{p} \varphi_{k l}^{p} \\
\varphi_{l k}^{p} \varphi_{l l}^{p}
\end{array}\right]\left[\begin{array}{l}
\Delta \ln k(t-p) \\
\Delta \ln l(t-p)
\end{array}\right]+\left[\begin{array}{l}
\varepsilon_{k}(t) \\
\varepsilon_{l}(t)
\end{array}\right]}
\end{aligned}
$$

where $\varepsilon_{k}$ and $\varepsilon_{l}$ are error correction terms obtained from the cointegrating regressions. If the estimate of $\lambda_{l}$ or $\varphi_{l k}^{j}(j=1, \cdots, p)$ is significant with a negative sign, $\ln k$ Granger-causes $\ln l$, and if the estimate of $\lambda_{k}$ or $\varphi_{k l}^{j}$ is significant and negative, $\ln l$ Granger-causes $\ln k$.

Next, to confirm whether the learning-bydoing process is justified, the long-run relationship between the productivity and capital is investigated. The rate of growth in the total factor productivity (TFP) is obtained by a difference in growth rates in output and input. To see the long-run relationship, cointegration analysis and the estimation of error correction model for $\ln T F P$ and $\ln K$ are conducted in the same method as before. Also, the Grangercausality tests are carried out to find directions of the relationships. If the learning-bydoing hypothesis is true, there must be causality from $\ln K$ to $\ln T F P$. These relationship should be positive, and the parameter of the error correction term should be negative if there are long-run relationships.

Stationarity in the series is examined by the
Augmented Dickey-Fuller (ADF) test, which explores whether the coefficient of the lagged level variable is significantly smaller than one. The critical values are taken from Fuller [8]. A time trend variable is also included in the equation to investigate the deterministic trend process. When serial correlation is detected, lagged difference variables are added until the serial correlation is not observed. Stationarity in the variable is also investigated by the test proposed by Kwiatkowski, et al. [13] (hereafter called the KPSS tests). This test examines a null hypothesis of trend-stationarity or levelstationarity against an alternative of nonstationarity, so that a more positive decision can be made when the true process is nonstationary. To test cointegration among the series, the Engle-Granger test is carried out. Again, lagged difference variables are added if a serial correlation exists. Critical values for the test are tabulated by Engle and Granger [6]. Moreover, Johansen's [9] trace test is applied to investigate the number of cointegrating vectors in the series. The critical values for the test are tabulated by OsterwaldLenum [18].

\section{Data}

Annual data are obtained from the Report on Production Cost of Rice, Wheat and Barley and Statistics of Prices and Wages in Rural Areas, compiled by the Ministry of Agriculture, Forestry and Fisheries of Japan (MAFF). The period of observation is from 1951 to 1995; thus the sample size is 45 , and the data covers all areas in Japan. This study uses the data for 2.0 to 3.0 hectare farms as a representative of farms that are above-average size, as well as the data for 0.3 to 0.5 hectare farms, those below the average size.

Although some previous production studies about Japanese agriculture use data for regions excluding Hokkaido, ${ }^{2)}$ the production technologies in farm production in the region are to some extent different from those in other regions of Japan; average-size farms in the region are larger than in other areas of Japan. Some data that are indispensable for estimation in this study, such as quantities consumed and prices for different qualities of rice, are available only at the national average. Mixing data at different levels of aggregation should be avoided, and consistency of data 
Induced Innovation with Endogenous Growth in Agriculture: A Case of Japanese Rice Production 19

collection should be maintained. Also, the reason why 2 to 3 hectare farms are used for the estimation, though the sample of "more than 3 hectares" is also available in the report of production costs, is because nearly half the observations in the latter group contains data for Hokkaido during the early period of the sample, so that estimating with the data is not necessarily preferable. ${ }^{3)}$ Farms of " 2 to 3 hectares" are still categorized as being larger than average, which are regarded in this study as the farms leading in innovations. Furtermore, using data of "more than 3 hectares" has a problem of small sample size. For example the size of sample for "more than 3 hectares" in the report of production costs is 46 in 1955, but that for "2 to 3 hectares" is 126 .

Methods of data collection in the production cost report have been changed several times. The gaps in the data series are adjusted by comparing those collected by the old and the new methods. A gap between data of land rent in 1975 and that in 1976 is corrected by using data in Ta-Hata Baibai Kakakutoh ni Kansuru Chose Kekka (Results of Survey on Sales Price of Rice and Upland Crop Field) compiled by Zenkoku Nogyo Kaigisho (Japan Agricultural Council). Because the report of production costs in 1995 presents data only for up to 0.5 hectare, instead of 0.3 to 0.5 hectare, the former is estimated from the latter by using proportions of sample size and production costs for up to 0.3 hectare and those for 0.3 to 0.5 hectare in the previous year.

All series affected by the inflation are deflated by the consumer price index. The amount of labor used for rice production is measured by working hours of household members and hired laborers. Data for labor are not adjusted by its characteristics, such as age, sex, physical strength, educational background, and other abilities, because few quantitative data concerning differences in terms of productivity are available.

The amount of capital is estimated by dividing the production costs for the categories by their prices and aggregating them into a series of the Divisia index. All kinds of physical input, including depreciation and repairing of machinery, fertilizers, pesticides, seeds, land rents, fees, and land improvement, are categorized as capital. Data aggregated for all capital inputs are used, since it is difficult to specify which inputs are contributed to an individual innovation. In rice production, various technological innovations have occurred simultaneously and changes in inputs often contribute several kinds of innovations. Changes in seeds, for instance, mainly contributed to the increases of rice yields before the 1970s, and they contributed to an improvement in the taste of rice after the 1970s.

Although more than two factors of production, such as labor, fixed capital, chemicals, and land, are used in many production function analyses, only two kinds of factors, labor and capital, are used in the model, since this situation fits well with an analytical framework of the endogenous growth model. Moreover, the sample size in this study is small for a time-series analysis, so that the use of many factors should be avoided because of the problem of degree of freedom.

The quantity of output is measured by the average weight of rice. An estimated TFP includes the effects of yield variations as a result of climate and other natural phenomena occurring stochastically. Because long-run relationships in production process are explored in this study, it is advisable to use data with as few variations as possible. This study makes adjustments for the series of TFP by applying a moving-average method for three periods, including the previous and subsequent data periods of the data.

In regard to adjustments for the quality improvement of rice, price premiums over the government-marketed rice are assumed to represent differences in quality between rice varieties. That is, the ratios of the price of rice that is not government-marketed to the price of rice that is government-marketed are assumed to be proportional to the ratio of quality levels between them. Japanese rice is classified by distribution channels into three kinds : that collected by the Japan Food Agency, called government-marketed rice; that marketed through semiprivate marketing channels, called Jishu Ryutsu Mai or voluntarily marketed rice; and that distributed by other marketing channels, as well as that for farmers' own consumption. It is assumed that the quality of voluntarily marketed rice and rice distributed by the other marketing channels are the same, and that the quality of rice for farmers' own consumption is equal to the average of all 
Table 1 (a). The augmented Dickey-Fuller test and Engle-Granger test for $\ln l$ and $\ln k$

\begin{tabular}{|c|c|c|c|c|c|c|}
\hline & \multicolumn{2}{|c|}{ ADF test } & \multirow{2}{*}{$\frac{\text { EG test }}{\ln k, \ln l}$} & \multicolumn{2}{|c|}{ ADF test } & \multirow{2}{*}{$\frac{\text { EG test }}{\ln k \ln l}$} \\
\hline & $\ln l$ & $\ln k$ & & $\ln l$ & $\ln k$ & \\
\hline$\rho$ & 0.892 & 0.630 & $0.338^{\prime \prime 0}$ & 0.983 & 0.971 & $0.217^{\circ+10}$ \\
\hline & $(-0.873)$ & $(-2.303)$ & $(-4.611)$ & $(-1.061)$ & $(-0.822)$ & $(-5.249)$ \\
\hline constant & $\begin{array}{l}-0.151^{\circ} \\
(-1.846)\end{array}$ & $\begin{array}{l}1.109^{\circ} \\
(2.361)\end{array}$ & $\begin{array}{l}2.802^{* *} \\
(46.304)\end{array}$ & $\begin{array}{l}-0.095^{\circ} \\
(-3.010)\end{array}$ & $\begin{array}{c}0.121 \\
(1.006)\end{array}$ & $\begin{array}{c}2.700^{\circ} \\
(101.188)\end{array}$ \\
\hline trend & $\begin{array}{c}-0.005 \\
(-0.743)\end{array}$ & $\begin{array}{l}0.007^{\circ} \\
(2.170)\end{array}$ & $\begin{array}{l}0.009^{\circ} \\
(1.896)\end{array}$ & $\begin{array}{l}n . a . \\
n . a .\end{array}$ & $\begin{array}{l}n . a . \\
n . a .\end{array}$ & $\begin{array}{l}n . a . \\
\text { n.a. }\end{array}$ \\
\hline DW-h & -0.144 & 1.342 & -1.126 & -0.198 & 0.151 & -1.126 \\
\hline BG & 0.040 & 1.802 & 0.962 & 0.126 & 0.164 & 0.962 \\
\hline$Q$ & 0.005 & 0.025 & 0.124 & 0.028 & 0.023 & 0.124 \\
\hline $\begin{array}{c}\text { coint. vector } \\
\text { lag }\end{array}$ & $\begin{array}{c}n . a . \\
1\end{array}$ & $\begin{array}{c}n . a . \\
1\end{array}$ & $\begin{array}{c}1,0.191 \\
0 \\
\end{array}$ & $\begin{array}{c}n . a . \\
1\end{array}$ & $\begin{array}{c}n . a . \\
1\end{array}$ & $\begin{array}{c}1,0.360 \\
0 \\
\end{array}$ \\
\hline $\begin{array}{l}\text { Note } \rho: \text { the } \\
\text { determined by } \\
\text { argumented } \mathrm{Di} \\
\text { Ljung-Box } Q \text { s } \\
\text { respectively. }\end{array}$ & $\begin{array}{l}\text { coefficient } \\
\text { the criterio } \\
\text { ckey-Fulle } \\
\text { tatistic. }\end{array}$ & $\begin{array}{l}\text { of the lag } \\
\text { n of no au } \\
\text { r test. E } \\
\text { 3G: Breus }\end{array}$ & $\begin{array}{l}\text { ariable in } \\
\text { rrelation. } \\
\text { t: Engle-G } \\
\text { odfrey LN }\end{array}$ & $\begin{array}{l}\text { key-Fulle } \\
\text { tics are it } \\
\text { est. DV }\end{array}$ & $\begin{array}{l}\text { ation. } \\
\text { ntheses. } \\
\text { Jurbin's } \\
\text { ficant at }\end{array}$ & $\begin{array}{l}\text { he lag length } \\
\text { F test: } \\
\text { tistic. } Q \text { : } \\
5 \%, 1 \% \text {, }\end{array}$ \\
\hline
\end{tabular}

Table 1(b). The augmented Dickey-Fuller test and Engle-Granger test for $\ln T F P$ and $\ln K$

\begin{tabular}{|c|c|c|c|c|c|c|c|c|c|c|}
\hline & \multicolumn{2}{|c|}{ ADF test } & \multirow{2}{*}{$\begin{array}{c}\text { EG test } \\
\ln T F P \\
\ln K\end{array}$} & \multicolumn{2}{|c|}{ ADF test } & \multirow{2}{*}{$\begin{array}{c}\text { EG test } \\
\ln T F P \\
\ln K\end{array}$} & \multirow{2}{*}{\multicolumn{2}{|c|}{$\begin{array}{cc}\text { ADF test } & \text { EG test } \\
\ln T F P(\text { Adj }) & \begin{array}{c}\ln T F P(\text { Adj }) \\
\ln K\end{array}\end{array}$}} & \multirow{2}{*}{$\frac{\text { ADF test }}{\ln T F P(A d j)}$} & \multirow{2}{*}{$\begin{array}{c}\text { EG test } \\
\ln T F P(A d j), \\
\ln K\end{array}$} \\
\hline & $\ln T F P$ & $\ln K$ & & $\ln T F P$ & $\ln K$ & & & & & \\
\hline$\rho$ & 0.706 & 0.975 & 0.470 & 0.885 & 0.988 & 0496 & $0.658^{\circ}$ & $0.367^{m}$ & 0.950 & 0.351 \\
\hline$r$ & $(-2.937)$ & $(-0.335)$ & $(-4.768)$ & $(-2.327)$ & $(-1.252)$ & $(-4.537)$ & $(-3.210)$ & $(-5.186)$ & $(-1.605)$ & $(-5.311)$ \\
\hline constant & $\begin{array}{l}0.015^{\circ} \\
(2.261)\end{array}$ & $\begin{array}{c}0.171^{\circ} \\
(0.640)\end{array}$ & $\begin{array}{c}-0.277 \\
(-2.060)\end{array}$ & $\begin{array}{c}0.017 \\
(2.491)\end{array}$ & $\begin{array}{c}0.125 \\
(2.431)\end{array}$ & $\begin{array}{l}-0.207^{* 4} \\
(-7.387)\end{array}$ & $\begin{array}{c}0.006 \\
(0.882)\end{array}$ & $\begin{array}{c}-0.341 \\
(-2.873)\end{array}$ & $\begin{array}{c}0.013 \\
(2.136)\end{array}$ & $\begin{array}{c}-0.405 \\
(-16.413)\end{array}$ \\
\hline trend & $\begin{array}{l}0.001 \\
(2.032)\end{array}$ & $\begin{array}{c}0.000^{\circ} \\
(0.172)\end{array}$ & $\begin{array}{c}-0.001 \\
(-0.537)\end{array}$ & $\begin{array}{l}n . a \\
n . a\end{array}$ & $\begin{array}{l}n . a \\
n . a\end{array}$ & $\begin{array}{l}n . a \\
n . a\end{array}$ & $\begin{array}{c}0.003 \\
(2.844)\end{array}$ & $\begin{array}{c}0.001 \\
(0.549)\end{array}$ & $\begin{array}{l}n . a \\
n . a\end{array}$ & $\begin{array}{l}n . a \\
n . a\end{array}$ \\
\hline DW-h & -1.144 & 1.562 & 0.568 & -0.415 & 1.306 & 0.634 & -1.178 & 0.473 & -0.184 & 0.405 \\
\hline BG & 2.636 & 1.769 & 1.202 & 0.343 & 1.481 & 1.511 & 2.424 & 0.376 & 0.008 & 0.272 \\
\hline $\mathrm{Q}$ & 0.753 & 1.585 & 0.147 & 0.162 & 1.486 & 0.177 & 0.699 & 0.081 & 0.033 & 0.061 \\
\hline $\begin{array}{l}\text { coint. } \\
\text { vector }\end{array}$ & n.a. & n.a. & $1,-0.084$ & n.a. & n.a. & $1,-0.064$ & n.a & $1,-0.092$ & n.a & $1,-0.111$ \\
\hline lag & 1 & 0 & 2 & 1 & 0 & 2 & 1 & 2 & 1 & 2 \\
\hline
\end{tabular}

Note $\rho:$ the coefficient of the lagged variable in the Dickey-Fuller equation. lag: the lag length determined by the criterion of no

autocorrelation. $t$-statistics are in parentheses. ADF test: argumented Dickey-Fuller test. EG test: Engle -Granger test. DW-h: Durbin's $h$-statistic. Q: Ljung-Box $Q$ statistic. BG: Breusch -Godfrey LM test. " "“, and ${ }^{\cdots}$ indicate statistical significance at $10 \%, 5 \%$, and $1 \%$, respectively.

kinds of rice. Data for the quantity of rice in each category are obtained from reports prepared by the Japan Food Agency [14] [15].

To compute the price premiums of voluntarily marketed rice, a difference in quality for each variety of this rice is assumed to be fixed at the base years of 1996-98. The quantity data for each variety of the voluntarily marketed rice are obtained from the Japan Food Agency [16], which includes most of the voluntarily marketed rice distributed in Japan. Then the weighted average of price premiums is calculated for each year, using shares of the varieties as a weight.

\section{Results of Estimation}

The results of the ADF tests of unit roots with and without a time trend in each test are reported in Table 1, (a) and (b). The notation of $T F P$ in the tables represents the series of the estimated TFP for 2 to 3 hectares of farm, which are not adjusted for quality of rice, but $T F P(A d j)$ is the estimated TFP adjusted for the quality. Also, $k$ and $l$ indicate the capital per output and the labor per output for 2 to 3 hectares of farm, and $K$ represents the capital per labor for it. All tests, except for $\ln T F P(A d j)$ with a trend, fail to reject the null hypotheses of unit roots at the $10 \%$ level. The KPSS tests with a lag reject the null hypothesis of trend stationary in all series except $\ln T F P(a d j)$ at the 5 percent level, and the tests for level stationarity with a lag reject the null hypothesis ${ }^{4)}$ (Table 2). Thus it is 
Induced Innovation with Endogenous Growth in Agriculture: A Case of Japanese Rice Production 21

Table 2. The KPSS test for stationarity in the series

\begin{tabular}{|c|c|c|c|c|c|c|c|}
\hline $\mathrm{H}_{0}$ & lag & $\ln k$ & $\ln l$ & $\ln K$ & $\ln T F P$ & $\ln T F P^{5}$ & $\ln T F P($ Adj $)$ \\
\hline Trend & 1 & $0.293^{\circ \cdots}$ & $4.510^{\circ *}$ & $0.579^{\circ+0}$ & $0.419^{\circ+1}$ & $0.467^{\circ 00}$ & 0.099 \\
\hline stationary & 2 & $0.192^{\circ *}$ & $2.319^{\circ \cdots}$ & $0.318^{* * \bullet}$ & $0.240^{\circ * *}$ & $0.258^{\circ \cdots}$ & 0.081 \\
\hline Level & 1 & $4.378^{\cdots \cdots}$ & $0.485^{\circ}$ & $4.527^{\circ * * *}$ & $3.493^{\circ \cdots *}$ & $0.784^{* * *}$ & $3.895^{\circ * *}$ \\
\hline stationary & 2 & $2.276^{* * *}$ & 0.291 & $0.579^{* *}$ & $1.835^{\circ * *}$ & $0.441^{\circ}$ & $2.106^{\circ * *}$ \\
\hline
\end{tabular}

Table 3. The Johansen Trace Test of cointegration for $\ln l$ and $\ln k$, and $\ln T F P$ and $\ln K$

\begin{tabular}{|c|c|c|c|c|}
\hline & \multicolumn{2}{|c|}{$\ln k \quad \ln l$} & \multicolumn{2}{|c|}{$\ln T F P \ln K$} \\
\hline & with trend & without trend & with trend & without trend \\
\hline $\mathrm{H}_{0}: \mathrm{r}=0$ & $22.719^{\circ}$ & $23.788^{\circ+10}$ & $21.324^{\circ \prime}$ & 21.816 \\
\hline $\mathrm{H}_{0}: \mathrm{r} \leq 1$ & 0.185 & 1.445 & 0.000 & 2.253 \\
\hline $\begin{array}{c}\text { lag } \\
\text { coint. vector }\end{array}$ & $\begin{array}{c}0 \\
1,0.424 \\
1,-1.487\end{array}$ & $\begin{array}{c}0 \\
1,0.381 \\
1,-0.101\end{array}$ & $\begin{array}{c}2 \\
1,-0.121 \\
1,1.246\end{array}$ & $\begin{array}{c}2 \\
1,-0.061 \\
1,-0.333\end{array}$ \\
\hline
\end{tabular}

concluded that a series besides $\ln T F P(A d j)$ follows a nonstationary process. The EngleGranger tests for $\ln k$ and $\ln l$ and those for $\ln T F P$ and $\ln K$, presented in Table 1 , show that there are cointegrating relationships between these pairs of series. Also, the Johansen's trace tests reject the null hypothesis of zero cointegrating vectors between the series at the 5 percent level, and the hypothesis of less than or equal to one cointegrating vector is not rejected at the level (Table 3). Furthermore, the signs of the cointegrating vectors for $\ln l$ and $\ln k$, as well as those of $\ln T F P$ and $\ln K$, are as expected.

The test results of the Granger-causality between $\ln k$ and $\ln l$, as well as those between $\ln T F P$ and $\ln K$, are presented in Table 4. The lags in the models are added until no serial correlations are detected at the $10 \%$ level. The $t$-statistic for the parameter of the error correction term $(\mathrm{E}(-1))$ in the equation of $\Delta \ln l$ is significant at the $10 \%$ level, but that in the equation of $\Delta \ln k$ is not significant at that level, which suggests one-way causality from capital investment to labor-saving innovation. Similarly, the causality tests between $\ln T F P$ and $\ln K$ imply one-way causality from capital investment to productivity growth.

These long-run relationships are supported by the results of estimation for the error correction models. Table 5 shows estimates for the model of $\ln l$ and $\ln k$ and the model of $\ln T F P$ and $\ln K$. In both models, the parameters of the exogenous trend (i.e., $\delta$ in Equation 5) are not significant, even at the $10 \%$ level. The

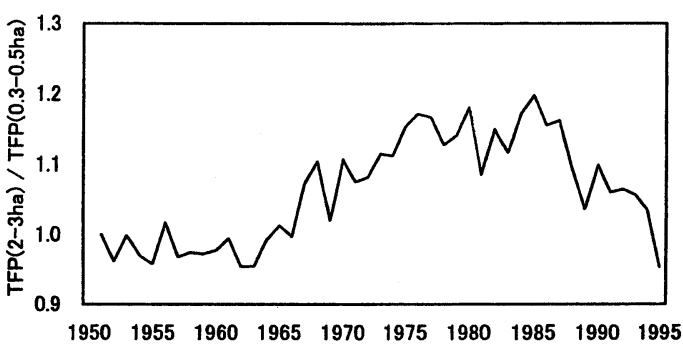

Figure 1. Ratio of the TFP for 2-3 ha to the TFP for $0.3-0.5$ ha

parameters of the level variables (i.e., $\phi$ in Equation 5) are significant and the signs of the estimates are as expected, implying innovation induced by capital investment.

The question remains whether there is technological spillover in a long run from the large-scale farms to the small-scale farms. Figure 1 presents changes in ratios of the TFP estimates for large-scale producers (i.e., 2 to 3 hectares here) to those for small-scale producers (i.e., 0.3 to 0.5 hectare). Since a large part of fluctuation in the estimated TFP is due to climatic effects, the ratios of the TFPs partially eliminate these unnecessary variations. The graph implies that growth of the productivity in the large farms precedes growth in the small farms. The productivity in the larger farms has risen faster since the late 1960s because of rapid mechanization, and the small farms has begun to catch up with the large ones since the early 1980s. This implies that technologies developed in the large farms have been transferred to the small farms.

Japanese rice production has been shifting toward the production of quality rice, most of which is marketed on the voluntarily marketed rice. Government-marketed rice makes up $61 \%$ of the total amount of production, excluding farmers' own consumption in 1975, and it dropped to $19 \%$ in 1990 (Japan Food Agency [14]). The price premium of the voluntarily marketed rice over the government-marketed rice, which is estimated by the method mentioned in the previous section, was $+4 \%$ in 
Table 4. The Granger-Causality Tests for $\ln l$ and $\ln k$, and $\ln$ TFP and $\ln K$

\begin{tabular}{|c|c|c|c|c|c|}
\hline & $\Delta \ln l$ & $\Delta \ln k$ & & $\triangle \ln T F P$ & $\Delta \ln K$ \\
\hline constant & $-0.036^{\circ}$ & 0.013 & constant & -0.005 & $0.041^{\circ}$ \\
\hline$E(-1)$ & $-0.203^{\circ}$ & -0.142 & $E(-1)$ & $-0.422^{\circ *}$ & 0.205 \\
\hline$\Delta \ln l(-1)$ & 0.029 & -0.119 & $\triangle \ln T F P(-1)$ & $0.425^{\circ \cdots}$ & -0.119 \\
\hline$\Delta \ln k(-1)$ & $-0.543^{\circ \cdots}$ & -0.212 & $\Delta \ln K(-1)$ & $0.098^{\circ}$ & 0.210 \\
\hline$\Delta \ln l(-2)$ & $\cdots$ & $\cdots$ & $\triangle \ln T F P(-2)$ & $0.328^{\circ}$ & -0.572 \\
\hline$\Delta \ln k(-2)$ & $\cdots$ & $\cdots$ & $\Delta \ln K(-2)$ & -0.062 & $-0.563^{\cdots \cdots}$ \\
\hline$\Delta \ln l(-3)$ & $\cdots$ & $\cdots$ & $\triangle \ln T F P(-3)$ & -0.146 & $1.136^{\circ}$ \\
\hline$\Delta \ln k(-3)$ & $\ldots$ & $\cdots$ & $\Delta \ln K(-3)$ & 0.0772 & $0.670^{\circ \cdots}$ \\
\hline DW-h & 1.246 & 0.532 & DW-h & -1.391 & 0.739 \\
\hline BG & 1.554 & 0.283 & BG & 1.935 & 0.547 \\
\hline Q & 0.339 & 0.632 & Q & 0.181 & 0.190 \\
\hline lag & & & lag & & \\
\hline
\end{tabular}

Note $E(-1)$ : error correction term obtained from the cointegrating regression. lag: the lag length determined by the criterion of no autocorrelation. DW: Durbin Watson statistic, DW-h: Durbin-Watson $h$-statistic for autocorrelation. $", "$, , and ${ }^{\cdots}$ indicate statistical significance at $10 \%, 5 \%$, and $1 \%$, respectively.

Table 5. Estimates of the error correction models

\begin{tabular}{|c|c|c|c|c|c|}
\hline & \multicolumn{2}{|c|}{$\Delta \ln l$} & \multicolumn{3}{|c|}{$\triangle \ln T F P$} \\
\hline$\Delta \ln k$ & 0.474 & $0.469^{\circ}$ & $\Delta \ln K$ & 0.264 & 0.259 \\
\hline$\lambda$ & $0.156^{* * * *}$ & $0.200^{* *}$ & $\lambda$ & $0.800^{* \cdots *}$ & $0.803^{* * *}$ \\
\hline $\ln \varphi$ & $-6.160^{* * *}$ & -4.422 & $\ln \varphi$ & 0.398 & 0.367 \\
\hline $\ln k(-1)$ & $-2.479^{* * *}$ & $-1.842^{\circ}$ & $\ln K(-1)$ & $0.111^{\ldots \ldots *}$ & 0.102 \\
\hline trend & $\cdots$ & -0.014 & trend & $\cdots$ & 0.000 \\
\hline DW & 1.676 & 1.619 & DW & 2.029 & 2.024 \\
\hline
\end{tabular}

$10 \%, 5 \%$, and $1 \%$, respectively.

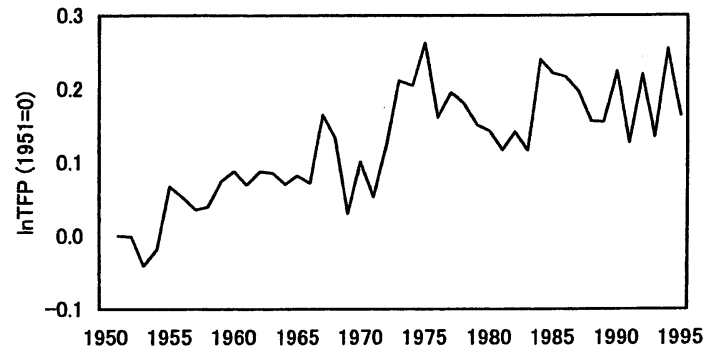

Figure 2. The estimated TFP, not adjusted for grade of rice (2-3 ha)

1975 , and it reached $+13 \%$ in 1990 . The adoptions of quality varieties have effects on income similar to those of the adoptions of highyielding varieties, and the production costs for quality rice are almost the same as the costs for conventional rice.

Supposing that unlimited improvement in productivity through capital-intensification is not feasible, as capital-based innovation become more difficult over time. Therefore it would be reasonable that innovators' efforts would shift toward innovations toward

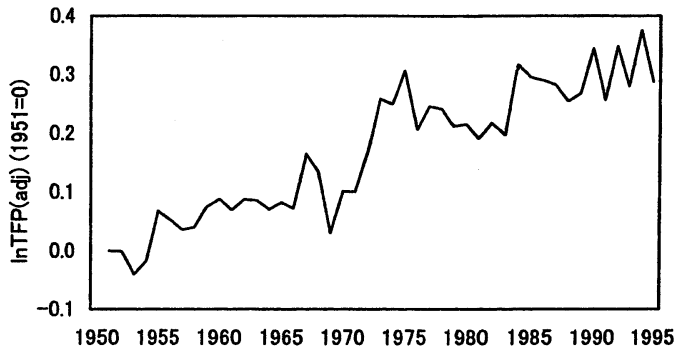

Figure 3. The estimated TFP adjusted for the grade of rice (2-3 ha)

improving product quality. Thus qualitybased innovation, is a substitute for capitalbased innovation, and the former should follow the latter. Back to Table 1(b), the TFP that takes account for quality improvement $(\ln T F P(a d j))$ follows a trend-stationary process, which suggests a continuous growth in productivity. Also, growth of the TFP estimates that do not include the effects of product quality improvement, as presented in Fig. 2 , has stagnated, and the TFP estimates, which do include the effects, as presented in Fig. 3, 
Induced Innovation with Endogenous Growth in Agriculture: A Case of Japanese Rice Production 23

Table 6. Annual growth rate of the TFPs and capital per labor

\begin{tabular}{cccc}
\hline period & $k$ & TFP & TFP(Adj) \\
\hline $1952-65$ & $5.32 \%$ & $0.68 \%$ & $0.68 \%$ \\
$1965-80$ & $9.40 \%$ & $0.42 \%$ & $0.87 \%$ \\
$1980-94$ & $4.42 \%$ & $0.34 \%$ & $0.77 \%$ \\
\hline $1952-94$ & $6.05 \%$ & $0.47 \%$ & $0.74 \%$ \\
\hline Note: The first and last period of the series are omitted due to the 3
\end{tabular}

period-moving average procedure for smoothing.

seem to grow continuously.

Furthermore, Table 6 compares the average growth rates in the capital per labor with the TFP growth rates. The annual growth rate of the TFP unadjusted for the quality is $0.7 \%$ for the pre-1965 period of observation, $0.4 \%$ for the $1965-1980$ period, $0.3 \%$ for the $1980-1994$ period, and $0.5 \%$ for the entire period. ${ }^{5)}$ It shows that the growth rate of the TFP has declined, as the growth rate of capital per labor has declined since the 1980s. On the other hand, the grow th rates of the TFP that count changes in the quality are $0.7 \%$ for the pre- 1965 period, $0.9 \%$ for the $1965-1980$ period, and $0.8 \%$ for the post-1980 period. In consideration of the improvement in product quality, it is inferred that the source of growth has gradually shifted from capital-base innovation toward quality-based innovation over the period.

\section{Concluding Remarks}

This study incorporates the mechanism of technological progress induced by capital investment into the conventionally induced innovation model. The time-series analyses on Japanese rice production provide evidence to support the endogenous technological change models of the learning-by-doing growth mechanism. The cointegrating relationship among the inputs implies an existence of the long-run growth path in the production. Also, the cointegration analyses between the TFP and capital also provide evidence for a longrun relationship between growth and investment. And the Granger causality tests show evidence of the productivity growth associated with capital investment. Moreover, the error correction model of the production function illustrates the process of endogenous technological changes.

The technological progress has gradually shifted from capital-based innovation to quality-based innovation as additional gains from the innovation based on capital investment become squeezed. Although a long-run growth of the productivity may not be achieved by capital-intensifying innovation, it can be achieved with improvement in product quality. From the standpoint that it is indirectly induced by diminishing marginal gains from capital-based innovation, it may also be regarded, in a broad sense, as a part of the endogenous innovation effects.

The model presented in this study requires modification of the conventional models of induced innovation. In regard to increases in wages, for examples, capital investment induces innovation toward labor saving, as suggested by the traditional induced innovation hypothesis, which also results in a growth in productivity. Thus it is likely that an innovation causes capital-using bias in the technological change. It also leads us to the implication that labor-saving mechanization may occur even if there is excess labor force in an economy.

Innovative ideas spill over because some producers in an economy are willing to develop new technology and others with more risk-averse preferences use the technology once it becomes available. Since the technological spillover from the innovative producers contributes to an improvement in productivity in the whole sector, the market involves the positive externalities. In this sense, positive public interventions to provide incentives to innovative producers are justified.

1) Steady-state equilibrium is defined as the condition where all economic variables change at the same rates.

2) However, to confirm the results of this paper, a similar kind of analysis by using the sample that excludes Hokkaido should also be carried out.

3) The proportion of observations for Hokkaido in the whole sample in the survey is a relatively small for farms of 2 to 3 hectares. Although Hokkaido accounted for $45 \%$ of samples of "more than 3 hectares" in 1960, it accounted for $20 \%$ of samples 
of "2 to 3 hectares." It should be noted that there might also be biases to some extent in the estimations that use the data from farms of 2 to 3 hectares.

4) The maximum lengths of lags in the KPSS tests are arbitrarily chosen, since apparent criteria to select these lag lengths are not necessarily available. However, truncation of lag that is too long is not preferable for small sample data with respect to consideration about the degree of freedom.

5) These estimates are within a reasonable range, compared with the other studies for rice production. For example, Doi's [5] estimates of the growth rates of TFP in terms of 2 to 3 hectares of Japanese rice farms are $0.2 \%$ for the period of 1959-69 and 1.0\% for 1969-79; Shintani's [23] estimate for the TFP of Japanese rice production, under the assumption of constant returns to scale, is $0.6 \%$ for the $1965-90$ period.

\section{References}

[1] Ahmed, I. and V. W. Ruttan, ed. Generation and Diffusion of Agricultural Innovations: The Role of Institutional Factors, Aldershot, England: Gower, 1988.

[2] Arrow, K. G. "The Economic Implications of Learning by Doing," Review of Economic Studies, Vol. 29, 1962, pp. 155-173.

[3] Barro, R. J. and X. Sala-i-Martin. "Convergence," Journal of Political Economy, Vol. 100, 1992, pp. 223251.

[4] Cameron, L. A. "The Importance of Learning in the Adoption of High-Yielding Variety Seeds," American Journal of Agricultural Economics, Vol. 81, 1999, pp. 83-94.

[5] Doi, T., "Inasaku Rodo Seisansei no Jyosho to Sono Yoin Bunseki (Increase in LaborProductivity in Rice Production and the Analysis of it's Factor)," in S. Sakiura, ed., Keizai Hatten to Nogyo Kaihatsu (Economic Development and Agricultural Development), Tokyo; Norin Tokei Kyokai, 1985, pp. 174-192.

[6] Engle, R. F. and Granger, C. W. J. "Cointegration and Error Correction: Representation, Estimation and Testing," Econometrica, Vol. 55, 1987, pp. 251-276.

[7] Foster, A. D. and M. R. Rosenzweig. "Learning by Doing and Learning from Others: Human Capital and Technical Change in Agriculture," Journal of Political Economy, Vol. 103, 1995, pp. 1176-1209.

[8] Fuller, W. A. Introduction to Statistical Time Series, New York: Wiley, 1976.

[9] Johansen, S. "Statistical Analysis of Cointegration Vectors," Journal of Economic Dynamic and Control, Vol. 12, 1988, pp. 231-254.

[10] Kako, T. "The Decomposition Analysis of Derived Demand for Factor Inputs: The Case of Rice
Production in Japan." American Journal of Agricultural Economics, Vol. 60, 1978, pp.628-635.

[11] Kawagoe, T., K. Otsuka, Y. Hayami. "Induced Bias of Technical Change in Agriculture: The United States and Japan," Joumal of Political Economy, Vol. 94, 1986, pp. 523-544.

[12] Kuroda, Y. "Biased Technological Change and Factor Demand in Postwar Japanese Agriculture, 1958-84," Agricultural Economics, Vol. 2, 1988, pp. 101-122.

[13] Kwiatkowski, D. and P. C. B. Phillips, P. Schmidt, and Y. Shin. 1992. "Testing the Null Hypothesis of Stationarity Against the Alternative of a Unit Root," Journal of Econometrics, 54, pp. 159178.

[14] Japan Food Agency, Beika ni Kansuru Shiryo (Statistics on Rice Prices). Ministry of Agriculture, Forestry and Fisheries, Various issues.

[15] Japan Food Agency, Seisansha no Beikoku Genzaidakatou Chosa Kekkahyo ( Report on Producers' Current Balance Sheet for Rice), Ministry of Agriculture, Forestry and Fisheries, Various issues.

[16] Japan Food Agency, Beikoku no Hinshubetsu Demawari Jokyo (Situation of Shipment by Rice Varieties), Ministry of Agriculture, Forestry and Fisheries, Various issues.

[17] Luh, Y. H. and S. E. Stefanou. "Learning-ByDoing and the Sources of Productivity Growth: A Dynamic Model with Application to U. S. Agriculture," Journal of Productivity Analysis, Vol. 4, 1993, pp. 353-370.

[18] Osterwald-Lenum, M. "Practitioners' Corner: A Note with Quantiles of the Asymptotic Distribution of the Maximum Likelihood Cointegration Rank Test Statistic," Oxford Bulletin of Economics and Statistics, Vol. 54, 1992, pp. 461-471.

[19] Pardey, P. G. and B. Craig. "Causal Relationships between Public Sector Agricultural Research Expenditures and Output," American Journal of Agricultural Economics, Vol. 71, 1989, pp. 919.

[20] Rogers, E. M. Diffusion of Innovations, Third Edition, New York: The Free Press, 1983.

[21] Romer, P. M. "Increasing Returns and LongRun Growth," Journal of Political Economy, Vol. 94, 1986, pp. 1002-1037.

[22] Sheshinski, E. "Optimal Accumulation with Learning by Doing," in K. Shell, ed., Essays on the Theory of Optimal Economic Growth, Cambridge, Mass.: MIT Press, 1967.

[23] Shintani, M. "Nogyo no Seisan Kansu no Keisoku: Tenbo (Measurement of Agricultural Production Function: A Survey)" Noringyo Mondai Kenkyu (Economic Review of Agriculture and Forestry), No. 100, 1990, pp. 138-145.

[24] Solow, R. M. Learning from "Learning-byDoing," Lessons for Economic Growth, Stanford, California: Stanford University Press, 1997. 
Induced Innovation with Endogenous Growth in Agriculture: A Case of Japanese Rice Production 25

[25] Wright, T. P. "Factors Affecting the Cost of Airplanes," Journal of the Aeronautical Sciences, Vol. 3, 1936, pp. 122-128.

[26] Yamaguchi, M. and C. H. Chen. "Sengo Nippon Nogyo Seicho no Keiryoteki Bunseki: Nogyo Shotoku Seicho no Shusoku nituite no Kensho (Econometric Analysis of Japanese Postwar
Agricultural Growth: A Test of Convergence of per Capita Agricultural Income Growth)," Nogyo Keizai Kenkyu (Journal of Rural Economics), Vol. 71, 1999, pp. 37-44.

(Received December 22, 1999; accepted October 27, 2000) 